\title{
Automatization for Product Quality as a SME Strategy to Compete Globally
}

\author{
SALOMÓN MONTEJANO GARCÍA \\ Professor, Autonomous University of Aguascalientes, México. \\ GABRIELA CITLALLI LÓPEZ-TORRES \\ Professor, Autonomous University of Aguascalientes, México. \\ Email: gabriela.lopez@edu.uaa.mx \\ Tel: +52(449)2462421
}

ROCÍO MONTSERRAT CAMPOS GARCÍA

Professor, Autonomous University of Aguascalientes, México.

\begin{abstract}
Businesses need to constantly maintain high quality in their products, and more importantly to remain competitive even at a global level, which is the current market pressure and need for many SME in countries underdevelopment, where more global enterprises have arrived leaving local businesses to the extreme of perishing. Therefore, already employed strategies in global companies to improve their product quality are essential to be reconsidered and to be implemented by local plants. Automation had become a highly important strategy in the manufacturing industry to satisfy customers and stand out from their competitors, more because today customers increasingly demand sustainable and higher quality products. The aim of this research was to validate the level of automatization and its effect onto product quality, in local, small, and medium enterprises (SME). A survey with two constructs was applied to manufacturing SME in the Aguascalientes region, Mexico. The data was analysed using SPSS-26 software. The regression analyses demonstrated that automation had a significant and positive effect on product quality in local SME, however, automatization is not recognized as a priority strategy leaving SME behind global competitive businesses in terms of product quality.
\end{abstract}

Keywords: Quality, Strategies, Management, SME, Manufacturing.

\section{Introduction}

It is well-known that a country's small and medium enterprises (SME) have a strong influence on its economy. And research has shown that the failure of SME is detrimental to the national economy. For example, in a country under development like Mexico, according to the National Institute of Statistics and Geography (INEGI, 2015) only six out of every ten service companies survive their first year and the life expectancy of these companies is eight years. Some others have studied the factors that lead to business failure, for example, a report by the Ministry of Economy (2010) mentioned that micro, SME are generally more adaptable than larger companies when faced with adverse conditions in the macroeconomic environment. However, because of their characteristics, SME face different issues, for instance, they rarely can participate in economic internationalization, and are separated from the most dynamic sectors of the economy, with reduced financing (only $25 \%$ have sources of financing) and an adequate and timely training. Thus, in general, SME have limited access to new technology and are generally separated from academia. 
Additionally, Jurado et al. (1997) determined that to avoid business failure, SME should focus on improving quality of their products and services because poor quality is one of the most important factors that prevents SME from distinguishing themselves from their competitors. In this sense, plants that produce goods and services have focused on various business aspects to become more competitive, on strategy is the automation of the company's production processes by implementing mechanical and robotic systems (Kamarudin, Mohammad, and Mahbub, 2015). Although SME that implement automation may not have the same production capacity as larger and global companies - each of which has its own pace and limitations, according to its own situation-SME must evolve and change in the face of growing competition.

During the 80s, many global companies began to operate in Aguascalientes city, Mexico, establishing a new era of high industrial performance and improving work conditions in the region. However, this situation represented for the local business not a positive effect, first because the local industry at that time was replaced by the newly arrived companies' assembly plants. The local industry suffered from the large companies' presence in the region and many local businesses disappeared (Gutiérrez, Hernández, and Alemán, 1999). Currently, local industry in Aguascalientes, México, in the need to grow at a rate comparable to that of the foreign companies that are moving into the region, it seems to be an opportunity for local economic development, and it may be beneficial for these SME to revaluate their business strategies; otherwise, they may fail or disappear. Hence, this is a difficult scenario for local industry to compete with foreign industry moving into the state; for this reason, the aim of this research is to analyse the differences between local and foreign companies, as well as, to validate the effect of automation on product quality.

\section{Automation}

Modern companies are constantly required to increase production capacity and improve product quality, more because every day, the demand for products and resources increases, and customers are also increasingly more selective. People have always sought to maximize capital gains while reducing efforts to obtain them. From the beginning, there have been institutions like slavery and serfdom, where people take advantage of others' physical labour, exploiting others' needs and weaknesses. But production processes have been revolutionized over time, mainly due to customer needs: customers require ever-increasing quantity, variety, and quality. In consequence, the manufacturing process has become increasingly more complex and complicated, as companies strive to offer competitive products and services in today's global market (Drury, 2000; Santorro, and De Masquita, 2008).

Before the steam engine, production was done by hand in rural environments. There were few specialized, highly-distinguished workers - a large, specialized workforce was not necessary, as product demand was low. There were also few places of production. The institution of apprenticeship ensured that products would continue to be produced for the little demand that existed. In terms of quality, customers mainly focused on product durability and endurance. However, in 1776, James Watt designed the steam engine, whose vapor-driven mechanical power could reduce or replace human labour in the production process. This invention completely changed the way we do things. Consequently, during this era, several machines were developed to reduce the need for human labour in the production process - and, while physical labour was still necessary, there was a marked increase in production capacity (Chiavenato, 1997).

Technology has contributed to development around the world. Automation goes together with technological advancement. Automation fulfils production tasks through mechanical, electrical, or electronic means, without directly involving any workers. The degree of automation in a company or factory can be determined by evaluating the ratio of the number of tasks performed by mechanical or electronic means to the number of total tasks performed at these sites. Automation is related to control systems, which are implemented to manage advanced technological equipment; this process generally involves information technology. In this sense, companies that opt for automation-a strategy that has been 
imposed upon many companies by globalization - can see substantial benefits, such as reduced costs, lower spending, and increased productivity and competitiveness. This is true whether these companies are principal manufacturers or devoted to outsourcing services. These companies may develop to the point of becoming part of the global supply chain, so among companies that make major contributions to the global economy (Chen, 2016). "The automation of industrial processes is one of the most important objectives as companies strive for competitiveness in today's changing and combative environment" (Moreno, 2011).

\section{Quality}

Today, product quality plays an important role in what is known as the "value chain" and anything that affects the production process - from beginning to end - is considered a defect. Even if companies produce the parts that are used early in the production process - and do not produce the final product that the user receives - they are considered part of the value chain, and the quality of the final product is linked to their performance. (Gelderman and Semeijn, 2006; Tracey, 2004). 'Product quality is the relationship between the product, the user, the user's expectations, and the services that are available if the product is defective or requires maintenance" (Shewhart, 1997). Therefore, for companies to survive in their early stages and to continue developing, they must select the right production processes to meet industry needs, in order to ensure quality products at a low cost (Lee, Ho, Choy and Pang, 2014).

According to Gokcen, Lachezar and Numan (2015) to implement control techniques for these production processes is key, also to update and improve all processes in the value chain. It should also be noted that these procedures increase the competitiveness and efficiency of all companies involved, especially in complex manufacturing processes, which require precision and reliability in their operations and assembly lines. It must be noted that relying on outsourced manufacturing can substantially diminish product quality, so companies should make several internal changes to ensure its product quality is not affected.

The main purpose of the referred internal changes is to verify that the contracted outsourcing service provider takes full responsibility for the quality of the products they provide, thus reducing the need to perform quality control tasks when the products are transported to the company's warehouses, which ensures product quality without consuming company resources. If companies have problems in this area, they must become more stringent to reduce risks when accepting products at their warehouses (Chen, 2116). Product quality will have well-defined parameters once the production processes that comprise the supply chain have been identified and organized, both the supplier and the buyer will have reached their objectives. The supplier will monitor their production processes, to avoid any quality-related problems with the buyer, and the buyer will be prepared to take on modes of operation that enable them to compete with larger enterprises.

In consequence, SME require important adaptations and new strategies, such as automation, when more global companies are in their region, to remain competitive, not to perish and be added to the value chain of these new globally competitive. It is interesting to validate the link of the current automation of SME to their product quality.

\section{The relationship between automation and product quality}

All companies that offer goods or services must ensure that the quality of their products satisfies customers and exceeds that of their competitors. Initially, this task was performed by evaluating company procedures, using statistics and methodological improvement tools, companies could identify and analyse root problems, thereby implement the most suitable solutions. Companies that operated in this way could improve results, reduce errors, and increase efficiency; however, these production processes still require a substantial amount of human labor and skilled workers to produce desirable results. The materials, precision tools, and technology used in the production process were still limited at this stage, and people were still required to perform their assigned tasks. 
To optimize the production process, it is necessary to understand that variability is the first enemy of quality, and a lower degree of variability indicates a higher degree of quality. One of the methods of reducing variability is automation, which in turn enhances product quality. even though this is the result of a combination of factors in the production process. Recent studies have confirmed that the automation of the precision measurement process has substantially enhanced product quality whenever implemented in the production process (Gokcen et al, 2014); these results are mainly obtained by eliminating the high degree of variability associated with human labour due to the workers' own capacities and their degree of fatigue. Automated processes are not subject to these natural limitations, and automated measurements are also more precise than those made by human workers.

For example, in the case of food production - where a high degree of sensitive precision is needed to meet minimum quality requirements - human labour has been replaced by automatic equipment, which is free of variability. Human labor, on the other hand, has a high degree of variability, as each worker has a different degree of sensitivity (Akarca, Çaglary Tomar, 2016). For example, mozzarella cheese production was improved by implementing various types of automated equipment, and product quality was improved as well. It has also been noted that, when assembling the machine parts used in precision movements, the assemblies produced by automated processes have a higher degree of precision than those assembled by hand (Filaretov, Zuev and Khvalchev, 2014). Implementing quality methods is a challenge for SME of their size, they have lower production volumes, resources, and worker skillsets than larger companies (GarridoVega, Sacristán-Díaz, \& Magaña-Ramírez, 2016). However, automation may be able to help smaller companies in this regard.

The main objective of this study is to develop an understanding of the level of automation in SME and its relationship to product quality in these SME examined. In particular, the hypothesis that will be tested is that automation positively impacts product quality in SME. This paper reviews the evidence for manufacturing SME operating in the Aguascalientes region in Mexico. Finally, this paper discusses and gives a summary of the findings.

\section{Materials and Methods}

The aim of this research is to demonstrate to influence of automation on product quality in SME context and. For that aim, a survey was applied to SMEs in the region of Aguascalientes, México. These companies have between 11 and 50 workers. Figure 1 shows the model that was used to evaluate the relationship between the two constructs. This model was used to develop the following hypothesis for this study: $\mathrm{H}_{0}$ : Implementing automation has a significant influence on product quality in SME.

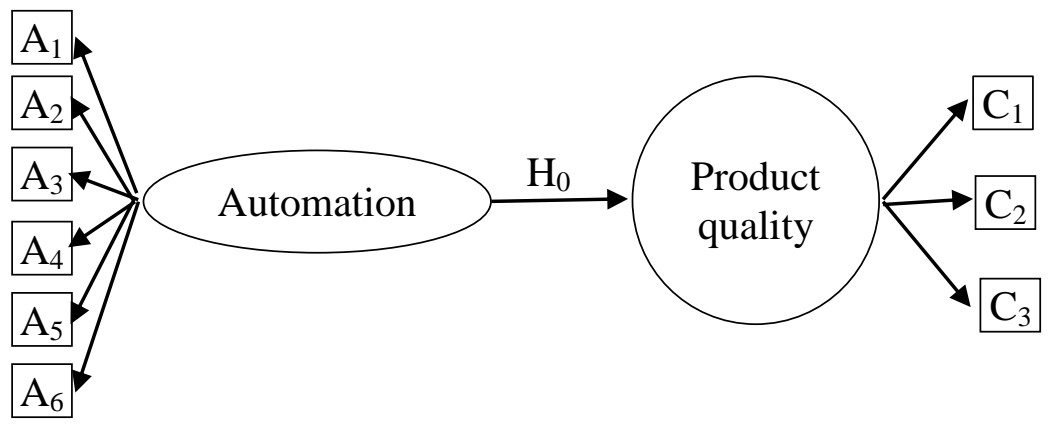

Figure 1 Conceptual illustration of a research model

The survey was administered to 307 companies with between 11 and 50 workers (INEGI, 2014) and it was administered to SME owners and managers. To measure the variable: product quality, three questions were adapted to obtain the opinions of company managers regarding product quality and company performance, employing the scale developed by Martin and Díaz (2009) and Urgal (2007). The other variable, 
automation, was composed of six questions designed to determine the degree of automation within the company. These questions were based on the information in Martinez, Garcia, and Maldonado (2010) and Maldonado, Martínez, Hernández and García (2011). A five-point Likert scale was used to analyse the data that was gathered, as shown in Table 1.

Table 1 Operationalization of variables

\begin{tabular}{|c|c|c|c|}
\hline Construc & Dimensions & Author & Qualification of variables \\
\hline 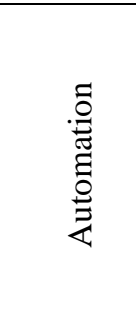 & $\begin{array}{l}\text { Automated production processes. } \\
\text { Machinery is operated by software. } \\
\text { Computer-assisted parts } \\
\text { manufacturing. } \\
\text { Traditional mechanical equipment. } \\
\text { Machinery is operated by computer } \\
\text { numerical control. } \\
\text { Quality controls are automated. }\end{array}$ & $\begin{array}{l}\text { (Martinez, Garcia } \\
\text { and Maldonado, } \\
\text { 2010) } \\
\text { (Maldonado, } \\
\text { Martínez, } \\
\text { Hernández and } \\
\text { García, 2011) }\end{array}$ & $\begin{array}{l}1=\text { Does not apply } \\
2=\text { Applies in some cases } \\
3 \quad=\text { Main processes are } \\
\text { automated } \\
4=\text { Most processes are } \\
\text { automated } \\
5=\text { All operations are automated }\end{array}$ \\
\hline : & $\begin{array}{l}\text { Products we manufacture are free } \\
\text { from defects. } \\
\text { Products comply with design } \\
\text { specifications. } \\
\text { There is a service that addresses } \\
\text { customer problems. }\end{array}$ & $\begin{array}{l}\text { (Martin and Diaz, } \\
\text { 2009) } \\
\text { (Urgal, 2007) }\end{array}$ & $\begin{array}{l}1=\text { Many quality issues } \\
2=\text { Frequent quality issues } \\
3=\text { Same amount of quality } \\
\text { issues as the competition } \\
4=\text { Occasional quality issues } \\
5=\text { Excellent quality }\end{array}$ \\
\hline
\end{tabular}

Source: Prepared by the authors, based on the variables proposed by Urgal (2007); Martin and Diaz (2009); Martinez, Garcia and Maldonado (2010); Maldonado, Martínez, Hernández and García (2011).

Subsequently, reliability tests were performed using the Cronbach's alpha to determine the variables' relevance according to the study model. The results are shown in Table 2 . In both cases, the result is greater than 0.7; therefore, the variables are considered relevant, and it is suitable to use them for the study model (Nunally and Bernstein 1994).

\begin{tabular}{|c|c|} 
Table 2 Reliability test results \\
\hline Construct & Cronbach's alpha: \\
\hline Automation & 0.795 \\
\hline \multicolumn{2}{|c|}{ Product Quality } \\
Source: Results of the reliability tests conducted by the authors
\end{tabular}

The tests reveal that the survey design accurately measures what it is intended to measure. SPSS-26 software was used to perform correlation and linear regression analyses for the data collected to test the hypothesis.

\section{Results}

The mean value for each item measured related to automation was calculated as shown in Figure 1 the lowest value was computer-assisted parts manufacturing, with a value of 2.03 and the highest was the traditional mechanical equipment (EMT) acquired an average value of 3.70.

Automated production processes (PPA) had an average response of 2.72 , indicating that only some companies have automated production processes; this average value is derived from the fact that $42.2 \%$ of respondents declared that a few processes were automated, and 29.3\% reported that automation is only used in special cases. Similarly, 28.6\% reported that, of all their production processes, only some processes are automated. The variable machinery is operated with some type of software (MTS) has an average response value of 2.23, indicating that SME only sometimes control their production processes using software. For this variable, $16.3 \%$ of managers reported that there are only a few processes carried out by traditional 
mechanical equipment. $22.4 \%$ reported that some important operations are still performed with traditional equipment, while $61.2 \%$ said that most equipment they use is traditional.

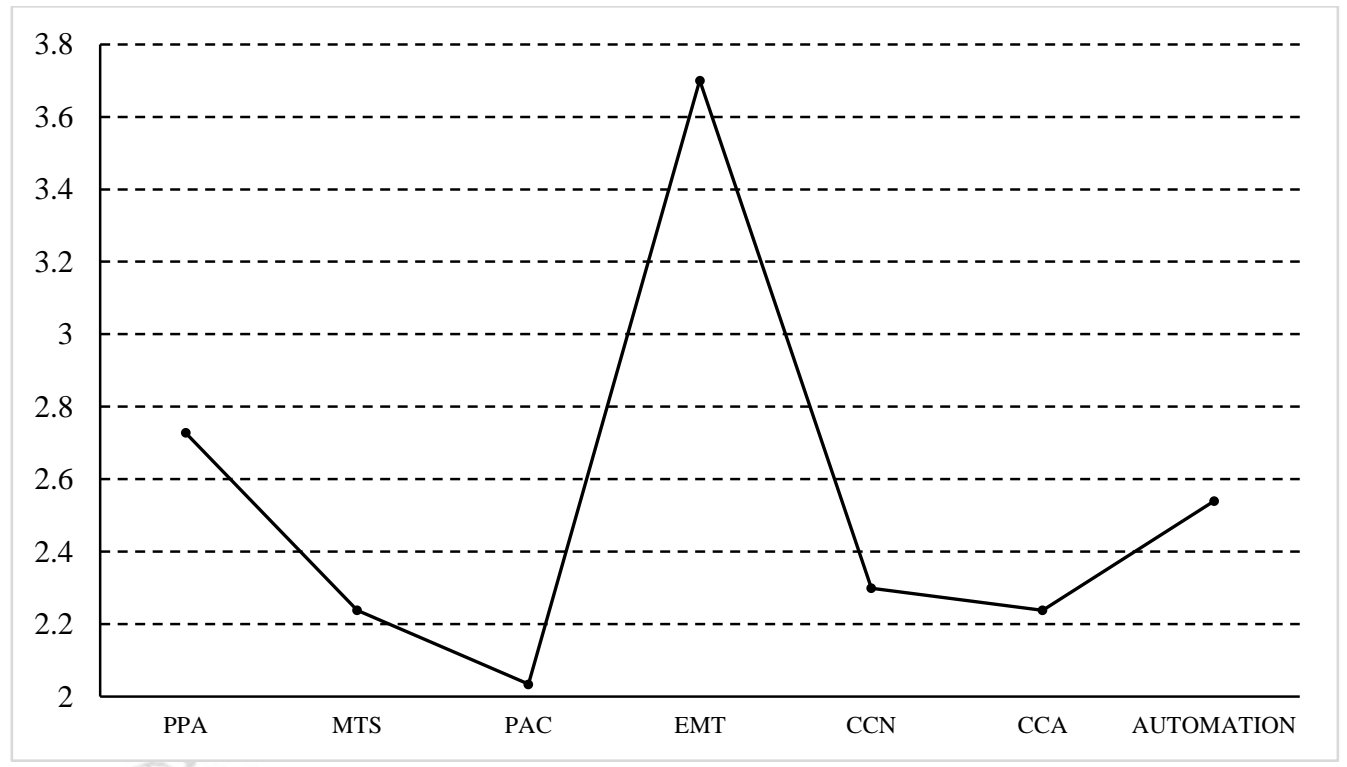

Figure 1 Average response values for each automation variable.

Source: by authors, based on survey results.

The variable computer-assisted manufacturing (PAC) obtained an average response value of 2.03, which is the lowest value in this variable, indicating that SME almost never use computer-assisted manufacturing. Whereas the $68 \%$ of managers reported that they almost never use automated processes; while $11.6 \%$ stated that only important processes were automated. On the other hand, $20.3 \%$ reported that most manufacturingrelated processes were computer-assisted. The traditional mechanical equipment (EMT) acquired an average value of 3.70, indicating that in SME most processes are performed using traditional mechanical equipment.

Moreover, the variable machinery is operated by computer numerical control (CCN) had an average value of 2.2. Thus, very little machinery is operated by computer numerical control, as reported by $57.8 \%$ of the respondents. $20.4 \%$ reported that the numerical control is used in the company's main processes, and $21.8 \%$ stated that numerical control is used in most company processes. Besides, the variable automated quality control (CCA) gained an average value of 2.23, which indicates that automated quality control is only used in some processes. $64.6 \%$ of managers reported that only some quality control processes are automated, while $11.6 \%$ reported that automated quality control is used only for the main processes within the company. Finally, $28.8 \%$ reported that most of their processes feature automated quality control.

The total average response for the construct of automation was 2.53, which indicates that there are not many automated processes in SME. This observation is since 58.5\% of managers reported that automation is uncommon in their companies; however, $25.9 \%$ of survey respondents said that their companies' main production processes are automated, and $15.6 \%$ reported that most operations are automated.

Figure 2 presents the results for the variables designed to measure the variable quality. The average response for the item of products we manufacture are free from defects (PSD), with a value of 3.4, indicating that these companies produce a similar number of defective products as their competitors. On the other hand, the highest-rated variable is there is a service that addresses customer problems (PCD), with a value of 4.0 . 


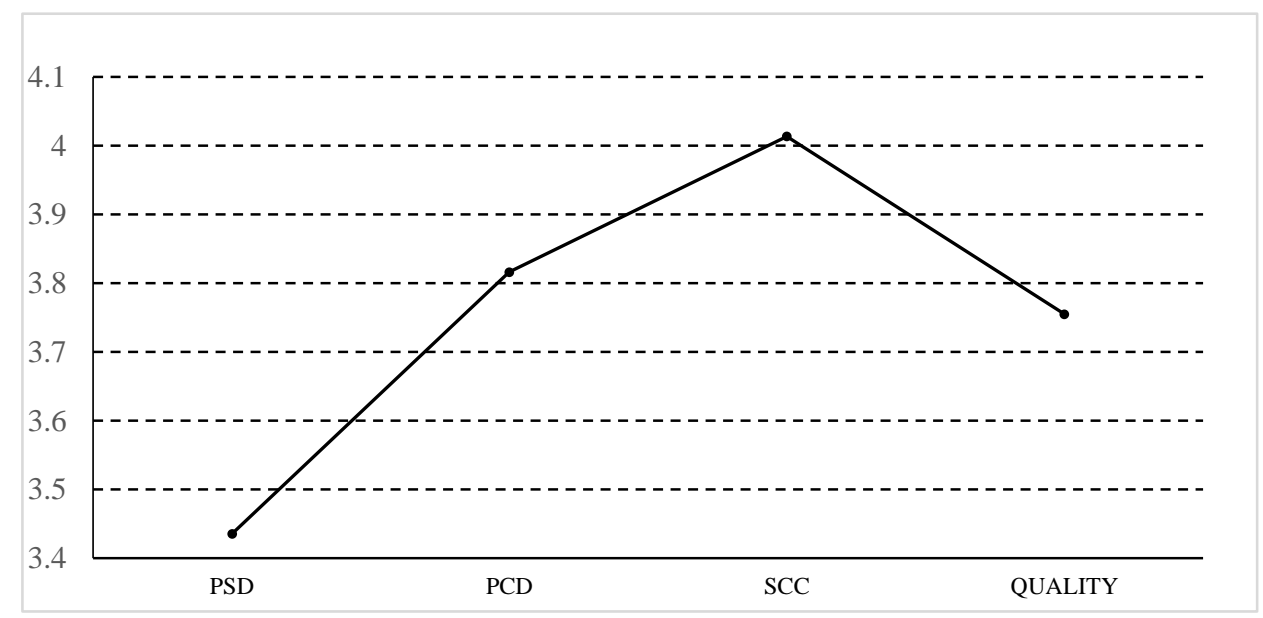

Figure 2 Average response values for each quality variable

The variable products are free from defects (PSD) has an average value of 3.4, indicating that managers of small companies in Aguascalientes believe they place a similar number of defective products on the market as their competitors. The $19.7 \%$ of respondents reported that their number of defective products is greater than that of their competitors, while $27.2 \%$ of managers stated that their number of defective products is equal to that of their competitors, and $53.1 \%$ stated that their number of defective products is lower than that of their competitors.

The variable products comply with design specifications (PCD) has an average value of 3.8 , indicating that managers of small companies reported that some defects occur because of failure to comply with design specifications. $9.5 \%$ of managers reported that defects in their products are due to noncompliance with design specifications. $20.4 \%$ stated that product defects are occasionally due to noncompliance with design specifications. $79.6 \%$ reported that it is very rare that product defects are due to noncompliance with design specifications.

The variable customer service support (SCC) received an average value of 4.01, indicating that SME generally have the resources to offer customer service. For this variable, $8.2 \%$ reported that they have rarely been able to offer customer support. And $17 \%$ of managers said they occasionally offer customer support. $74.8 \%$ of managers said they have the resources to offer customer support most of the time.

The average value for all responses in terms of product quality is 3.75 , indicating that managers reported that their company's level of quality is slightly above that of their competitors and that they have fewer product defects. For this variable, $8.8 \%$ of managers reported that they frequently find defects in their products, while $21.1 \%$ of respondents said that their level of quality - in terms of the number of defective products delivered to customers - is like that of their competitors. The $70.1 \%$ stated that their company's level of quality is greater than that of their competitors, and that defects are only rarely found in their products.

A correlation analysis was performed for the relationship between the two constructs (automation and product quality), where the correlation value was 0.33 , which means the correlation is significant. The Rsquared value is 0.11 , which means that automation accounts for an $11 \%$ increase in product quality. Therefore, the research hypothesis is not rejected: Implementing automated processes has a positive and significant influence on product quality in small businesses in Aguascalientes region, in Mexico. Figure 2 shows the correlations between the variables. $19.2 \%$ of respondents stated that their company has very few automated processes and the company's product quality is very low. Similarly, $34.6 \%$ stated that many 
processes are automated in the company and their company has a high degree of product quality. On the other hand, $46.2 \%$ said that, while few processes are automated in the company, the level of product quality is high.

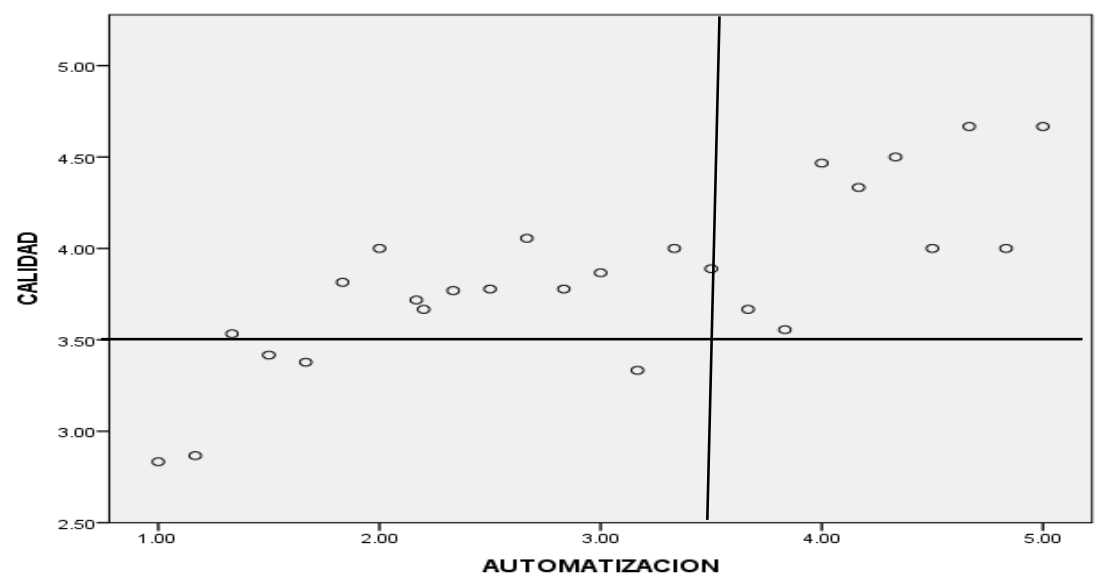

Figure 2 The correlation between automation and product quality in SME.

A linear regression analysis was performed to complement the correlation analysis to determine the influence of automation more clearly on product quality in SME. Automation is considered the independent variable, and quality is considered the dependent variable (Table 3).

Table 3 Results of the linear regression analysis for automation and quality.

\begin{tabular}{|l|c|c|c|c|c|}
\hline \multirow{2}{*}{} & \multicolumn{2}{|c|}{ Non-standardized coefficients } & Standardized coefficients & \multirow{2}{*}{ S } & Sig. \\
\cline { 2 - 5 } & $\mathrm{B}$ & Standard error & Beta & 15.35 & .000 \\
\hline (Constant) & 2.986 & .194 & .332 & 4.234 & .000 \\
\hline AUTOMATION & .303 & .072 & & .32 & \\
\hline
\end{tabular}

Source: Prepared by the authors based on data analysis results.

\section{Discussion}

This research examined the linkage between automation and product quality in SMEs. The findings of this study demonstrate that automation has a positive and significant impact on product quality in SME examined. Also, SME mainly use traditional equipment. The area that was considered with the lowest value was the use of computer-assisted parts manufacturing. This is similar to research carried out on SMEs in India, where it was stablished that the current models were not sufficient for SME to reach global competitiveness (Sharma, Durgesh, Ali, 2010), this is to say that SMEs in order to obtained most advanced levels of flexibility integration and automation require advanced systems, such as, computer integrated manufacturing (CIM), flexible manufacturing system (FMS), or reconfigurable manufacturing system. In fact, according to the National Manufacturing Competitiveness Council (NMCC), the areas in manufacturing means that needs improvement are in the first place, technology infrastructure, followed by production management, design/ innovation expertise, and quality management.

As mentioned in the literature review, even though the several advantages provided by automation, for instance, deliver quality products and saving time (Palaščáková, 2016) as relevant elements in production, there are few firms adopting this capability. In this sense, the current study found that the highest value was given to traditional mechanical equipment (EMT). Thus, only few firms have automated production 
processes through some type of software, and the highest number of firms use traditional equipment. In consequence, the results of this study indicate that the lowest average response for the variable of automation was in the element computer-assisted manufacturing (PAC). Another important finding was that $57.8 \%$ use little machinery operated by computer numerical control (CCN).

These findings further support the idea of SME having in general low automation levels, therefore could have low product quality. A possible explanation for these results may be the lack of adequate awareness and proactivity of owners, managers to improve their business participation to response to competitive market pressures, like, improve product quality, and deal with occupational health and safety (Sharif \& Huang, 2019). In fact, it is interesting to note that in this research, measuring the variable of product quality, the element of service that addresses customer problems was the highest valued, which indicates that owners and managers believe their companies are better in solving customer problems than their competitors.

On the question of how they consider their products free from defects, most respondents consider that the number of defective products is lower than their competitors and that very rare their product defects are due to noncompliance with design. In this regard, SME could adopt new capabilities, such as automation, to improve their product quality. For example, design, such as rule-based design (RBD) to automate the design of products, as Chavali et al. (2008) presented. However, SMEs apparently require to continuously evaluate and improve their benchmarking actions, along with the improvement of capabilities, like automation, to advance their competitiveness to a flexible manufacturing level.

\section{Conclusions}

In conclusion, the results of this study indicated that, for the SME that were analysed, automation has a positive and significant influence on product quality. This is that product quality is directly related to the degree of automation in SME. Thus, businesses that focus on automating their production processes also see an increase in their product quality. However, in contrast, the results indicate that SME are far from becoming fully automated, as $58.2 \%$ of managers reported that only a few processes are currently automated in their companies. In contrast, $70 \%$ said that they rarely experience problems related to product quality.

It seems that if businesses owners do not prioritize automation, their products will be of similar or lower quality as those of their competitors. If business owners want to stand out, they should focus on automating their production processes, one by one, until the majority are automated. As a result, defects will be reduced, and the company will have a higher degree of quality than its competitors. The SMEs analyzed reported that they do not prioritize automation as much as other companies in the industry, as business owners reported they are rarely focused on increasing the degree of automation in their companies. This situation can be attributed to the cost and (occasionally) the inaccessibility of automation technology, which is mainly targeted at larger companies; for this reason, implementing this technology in SME can be complicated.

However, it seems that SME managers and owners need promote the automatization of production processes if they want to become globally competitive as the foreign and large plants coming to their region. By using industrial engineering techniques-which can be implemented via the collaborative effort of management-supported work teams. Hence, companies can save resources and finance larger projects. In this sense, assessing their current level of automatization is possibly the first step to implement a solution, by determining their level of automatization and product quality, companies can create a focused plan for continuous improvement, to stand out from supply chains of foreign companies and ultimately become globally competitive businesses. 


\section{References}

Akarca, G., Çaglar, A. \& Tomar, O. (2016). The effects spicing on quality of mozzarella cheese. Mljekarsstvo. 66 (22), $112-121$.

Chavali, S. R., Sen, C., Mocko, G. M., \& Summers, J. D. (2008). Using rule based design in engineer to order industry: An SME case study. Computer-Aided Design and Applications, 5(1-4), 178-193. https://doi.org/10.3722/cadaps.2008.178-193

Chen, J. (2016). Sourcing for quality: Cooperating with a single supplier or developing two competing suppliers? Hiundwi Publishing Corporation 1, 1-13.

Chiavenato, I. (1997). Introducción a la teoría general de la administración. Santa Fe de Bogotá, D.C. Colombia: Mc Graw Hill.

Drury, C.G. (2000). Global quality: linking ergonomics and production. International Journal Production Research. 38(17), 4007 - 40018.

FAO. (2009). La agricultura mundial en la perspectiva del año 2050. Foro de Expertos de Alto Nivel. Roma 12 al 13 de Octubre.

Filaretov, V., Zuev, A. y Khvalchev, A. (2014). Development of approach to automatic machining of composite parts without their rigid fixing by means of multilink manipulators. Procedia Engineering. 69 (1), $4-12$.

Garrido-Vega, P., Sacristán-Díaz, M., \& Magaña-Ramírez, L. M. (2016). Six Sigma in SMES with low production volumes. A successful experience in aeronautics. (English). Universia Business Review, (51), 52-71. doi:10.3232/UBR.2016.V13.N3.02

Gelderman, C. J. y Semeijn, J. (2006). Managing the global supply base through purchasing portfolio management. Journal of Purchasing and supply Management. 12 (4), 209 - 217.

Gokcen, B., Lachezar, S. y Numan, N. D. (2015). Assessment of production quality in machining by integrating a system of high precision measurement. Procedia Engineering. 100 (1), 1616 -1624.

Gutiérrez, C. D., Hernández, R. M. y Alemán, L. R. (1999). Nuevas estrategias de modernización empresarial en Aguascalientes. Aguascalientes, México: Universidad Autónoma de Aguascalientes.

INEG. (2014). Censos económicos 2014. Bajado de:

http://www.inegi.org.mx/est/contenidos/Proyectos/ce/ce2014/doc/minimonografias/mpymesce2014.pdf

INEGI (2015). Esperanza de vida de los negocios. Boletín de prensa, 087/15, 1-2.

Kamarudin, S. S., Mohammad, M. F. y Mahbub, R. (2015). Barriers and impact of mechanization and automation in construction to achieve better quality products. Procedia Social and Behavioral Sciences. 222, $11-120$.

Lee, C, K, H., Ho, G, T, S., Choy, K, L. y Fang, G, K, H. (2013). A RFID-based recursive process mining systems for quality assurance in the garment industry. International Journal of Production Research. $52(14), 4216-4238$.

Maldonado, G. G., Martinez, S. M. C., Hernández, C. O. y Garcia, P. L. D. (2011). El impacto de los procesos de producción en el rendimiento de la Pyme manufacturera de México: Un estudio empírico, TEC Empresarial, Escuela de Administración de Empresas, 5(1), 21 - 30.

Martín, P. M. L. y Díaz, G. E. (2009). Posicionamiento estratégico de las empresas industriales en las prioridades competitivas de operaciones: Desarrollo y aplicación de un indicador de medida. Cuadernos de Economía y Dirección de Empresas, 39, 59 - 94.

Martínez, S. M. C., García, P. L. D. y Maldonado, G .G. (2010). Innovación y gestión del conocimiento, en la Pyme de Aguascalientes. México: Universidad Autónoma de Aguascalientes.

Mintzberg, H., Bruce, A. y Lampel, J. (1998). Stratgy safari. A guided tour through the wilds of strategy management. New York. USA: The free press.

Moreno, E. G. (2011). Automatización de procesos industriales. A. omega, Ed. Alfa omega.

Nunnally, J. C. and Bernstein, I. H. (1994): Psychometric Theory. $3^{\mathrm{a}}$ ed. Nueva York, NY: McGraw Hill.

Palaščáková, d. (2016). Insight into the Programming of Machine Tools. Acta technica corviniensis Bulletin of Engineering, IX(4), 9-12.

Richard, R. B. (2005). Industrialised building systems: Reproduction before automation and robotics. Automatization in Construction. 14. $442-451$. 
Santorro, M. C. y De Mesquita, M. A. (2008). The effect of the workload on due date performance in job shop scheduling. Brazilian journal of Operation \& Production management, 5(1), 75 - 88

Secretaría de Economía. (2010). Documento informativo sobre las PYME's en México. Consultado online en Noviembre 24 de 2010, en: http://www.cipi.gob.mx/html/..\%5CPol Apoyo PyME's Mex.PDF

Sharif, N., \& Huang, Y. (2019). Industrial automation in china's "workshop of the world." China Journal, 81(1), 1-22. https://doi.org/10.1086/699471

Sharma, D., \& Ali, M. (2010). Framework for Implementing Flexible Automation in Indian Industries. Global Business and Management Research 2.2/3, 3(2), 208-223.

Shewhart, W. A. (1997). Control económico de la calidad de productos manufacturados. Ediciones Diaz de Santos.

Tracey, M. (2004). Transportation effectiveness and manufacturing firm performance. International Journal of Logistics Management. 15 (2), 31 - 50.

Urgal, G. B. (2007). ¿Cómo influye la infraestructura de producción en el rendimiento de las empresas manufactureras. Cuaderno de Gestión, 7(2), 13 - 27.

Vargas, H. J. G. y Guillén, M. I. J. (2005). Los procesos de transformación estratégica en relación con la evolución de las organizaciones. Estudios Gerenciales. 94, 65 - 80

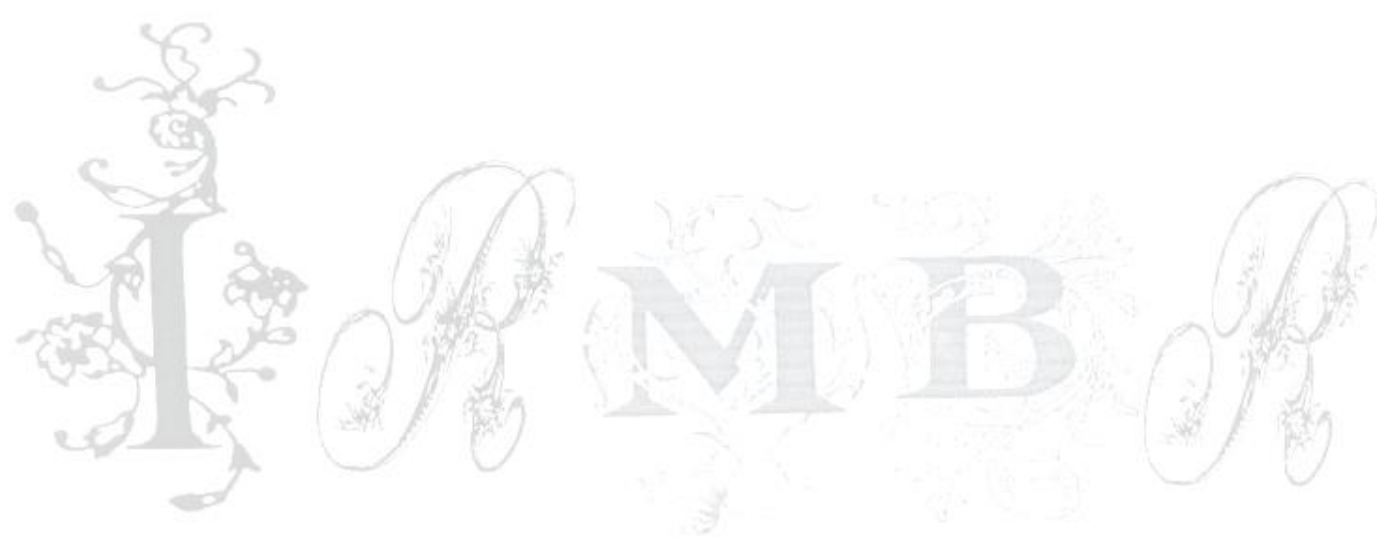

